\title{
Toxicity of entomopathogenic fungal culture filtrate of lowland and highland soil of South Sumatra (Indonesia) against Spodoptera litura larvae
}

\author{
MIMMA GUSTIANINGTYAS ${ }^{1}$, SITI HERLINDA ${ }^{1,2,3,}$, SUWANDI $^{1,2,3}$, SUPARMAN $^{1,2}$, HARMAN HAMIDSON $^{1,2}$, \\ HASBI $^{3,4}$, ARUM SETIAWAN ${ }^{5}$, MARIESKA VERAWATY ${ }^{5}$, ELFITA $^{6}$, ARSI $^{2,3}$ \\ ${ }^{1}$ Program of Crop Sciences, Faculty of Agriculture, Universitas Sriwijaya. Palembang 30139, South Sumatera, Indonesia \\ ${ }^{2}$ Department of Plant Pests and Diseases, Faculty of Agriculture, Universitas Sriwijaya, Indralaya 30662, South Sumatra, Indonesia. \\ Tel.: +62-711-580663, Fax.: +62-711-580276, `email: sitiherlinda@unsri.ac.id \\ ${ }^{3}$ Research Center for Sub-optimal Lands (PUR-PLSO), Universitas Sriwijaya. Palembang 30139, South Sumatera, Indonesia \\ ${ }^{4}$ Department of Agricultural Engineering, Faculty of Agriculture, Universitas Sriwijaya. Indralaya, Ogan Ilir 30662, South Sumatra, Indonesia \\ ${ }^{5}$ Department of Biology, Faculty of Mathematics and Natural Sciences, Universitas Sriwijaya. Indralaya, Ogan Ilir 30662, South Sumatra, Indonesia \\ ${ }^{6}$ Department of Chemistry, Faculty of Mathematics and Natural Sciences, Universitas Sriwijaya. Indralaya, Ogan Ilir 30662, South Sumatra, Indonesia
}

Manuscript received: 6 March 2020. Revision accepted: 7 April 2020.

\begin{abstract}
Gustianingtyas M, Herlinda S, Suwandi, Suparman, Hamidson H, Hasbi, Setiawan A, Verawaty M, Elfita, Arsi. 2020. Toxicity of entomopathogenic fungal culture filtrate of lowland and highland soil of South Sumatra against Spodoptera litura larvae. Biodiversitas 21: 1839-1849. The use of secondary fungal metabolites for the active ingredient of mycoinsecticide is more effective and more easily integrated with other pest control techniques. This study aimed to measure the toxicity of the culture filtrate of entomopathogenic fungi originating from South Sumatra against the Spodoptera litura larvae. Beauveria bassiana (25 isolates) and Metarhizium anisopliae (20 isolates) of South Sumatra were cultured in liquid media and filtered to produce culture filtrate. The larvae which were sick due to the filtrate showed the symptoms of decreased appetite and were not actively moving, while the dead larvae were characterized by being wrinkled, dry, black integument, and odorless. Mortality caused by B. bassiana filtrate was the highest $98 \%$ (BJgTs isolate) and not significantly different from the BSwTd2 isolate (94.67\%). Yet, the $\mathrm{LT}_{50} \mathrm{BSwTd} 2$ isolate was shorter (5.92 days) compared to the $\mathrm{LT}_{50} \mathrm{BJgTs}$ isolate (6.35 days). The most toxic M. anisopliae filtrate produced the mortality of $96 \%$ (MKbTp2 isolate) and $85.33 \%$ (MPdB isolate) each of which had $\mathrm{LT}_{50}$ of 7.36 days and 8.09 days, respectively. So, the most toxic culture filtrate was BSwTd2 isolate of B. bassiana and MKbTp2 isolate of M. anisopliae. The entomopathogenic fungi producing filtrate which are toxic have the potential to be active ingredients of mycoinsecticides.
\end{abstract}

Keywords: Beauveria bassiana, chili, LT50, Metarhizium anisopliae, mortality

\section{INTRODUCTION}

South Sumatra is generally dominated by lowland lands, namely freshwater swamps and tidal lowlands (Kartika et al. 2018; Karenina et al. 2019), and a small portion of medium and highland. Freshwater swamps can be found, among others in the Districts of Ogan Ilir, Ogan Komering Ilir, Musi Banyuasin, and Palembang City; the widest tide exists in Banyuasin District and the medium and highlands occur, among others, in the Districts of Ogan Komering Ulu Selatan, Lahat, and Pagaralam City. The varied topographical conditions between districts/cities characterize the differences including the crops and microorganisms cultivated there.

In the lowlands of South Sumatra are generally cultivated annual crops, such as paddy (Herlinda et al. 2018a; Prabawati et al. 2019), maize (Juhriah et al. 2019), chili (Johari et al. 2016; Nasution and Respatijarti 2019; Sagrim et al. 2017), and palm oil (Darlan et al. 2016). Meanwhile, in the medium and high plains are generally cultivated annual crops such as coffee, tea (Zamhari et al. 2017), vegetables such as potatoes (Maryanto et al. 2018), cabbage, mustard greens, and caisim (Situmorang et al.
2019). Vegetables and seasonal plants of the lowlands and highlands generally have a major pest, namely Spodoptera litura (Turnip et al. 2019). The yield loss caused by its larval stage is more than 35\% a year (Bueno et al. 2011). This pest has egg, larval, pupal, and adult stages (Vijaya and Rani 2016). S. litura is a polyphagic pest that attacks many vegetables in Indonesia, for example, chili (Nagal et al. 2016), cotton fruit (Maqsood et al. 2017), soybean (Fattah et al. 2018). A polyphagic pest is a pest that has a broad range of host species (more than a family) (Nagal et al. 2016). For the control of S. litura, it needs natural enemies such as entomopathogenic fungi that can adapt in low to high altitudes.

In the lowlands and highlands, the soil types have different chemical and physical characteristics; acidic $\mathrm{pH}$ soils are generally found in the lowlands and neutral or basic $\mathrm{pH}$ soils are found in the highlands (Munir and Herman 2019). Soil $\mathrm{pH}$ can affect the presence of entomopathogenic fungi and tends to be neutral or high $\mathrm{pH}$ soils which more commonly occur in entomopathogenic fungi than low $\mathrm{pH}$ soils (Safitri et al. 2018). Besides $\mathrm{pH}$, the texture of sandy soils tends to be low and muddy which is not suitable for fungal propagule life as well as water- 
saturated soil where fungi are rarely spotted to survive (Garrido-Jurado et al. 2011). Temperature (Pinnamaneni et al. 2010) and humidity (Oreste et al. 2015; Liu et al. 2017) also affect pathogenicity of entomopathogenic fungi.

Previous study found that more than 30 isolates of entomopathogenic fungi were found in the freshwater swamp, tidal, and highland soil of South Sumatra (Safitri et al. 2018). Apart from the soil, the entomopathogenic fungi were also found from the insect pests of vegetable and food crops of the lowlands to the highlands of South Sumatra (Herlinda et al. 2018b). Various origins of entomopathogenic fungi tend to produce pathogenicity variations (Sumikarsih et al. 2019).

The pathogenicity of entomopathogenic fungi is influenced by the ability of the fungi to produce secondary metabolites (Zibaee et al. 2009). The fungi that develop in insect hemolymph or in liquid media are able to produce toxic metabolites, such as extracellular enzymes, proteins, and toxins (Bandani 2005). In vitro media, toxic metabolites can be produced by the fungi which are grown in liquid media and produce culture filtrate (Soesanto et al. 2019). The use of secondary entomopathogenic fungal metabolites for the active ingredient of mycoinsecticide is more effective and more easily integrated with other pest control techniques (Zibaee et al. 2009). Entomopathogenic fungal culture filtrate found in low to high altitude of South Sumatra potentially gets the most toxic isolates that can be utilized in the development of mycoinsecticide technology. For this reason, this study aimed to measure the toxicity of the culture filtrate isolates of entomopathogenic fungi from low to high land of South Sumatra, Indonesia against Spodoptera litura larvae.

\section{MATERIALS AND METHODS}

The experiments were carried out at the Entomology Laboratory, Department of Pests and Plant Diseases, Faculty of Agriculture, Universitas Sriwijaya from May to November 2018. The room temperatures and relative humidity during the experiment in the laboratory were $29.78^{\circ} \mathrm{C}$ and $82.72 \%$, respectively. The entomopathogenic fungi isolates used in this study were explored by Herlinda et al. (2018) and Safitri et al. (2018), (Table 1 and 2) spread from the lowlands to the highlands of South Sumatra. The isolates were grouped into two: 25 isolates of Beauveria bassiana (Figure 1) and 20 isolates of Metarhizium anisopliae (Figure 2). All isolates were identified by Dr. Suwandi (a mycologist from Universitas Sriwijaya).

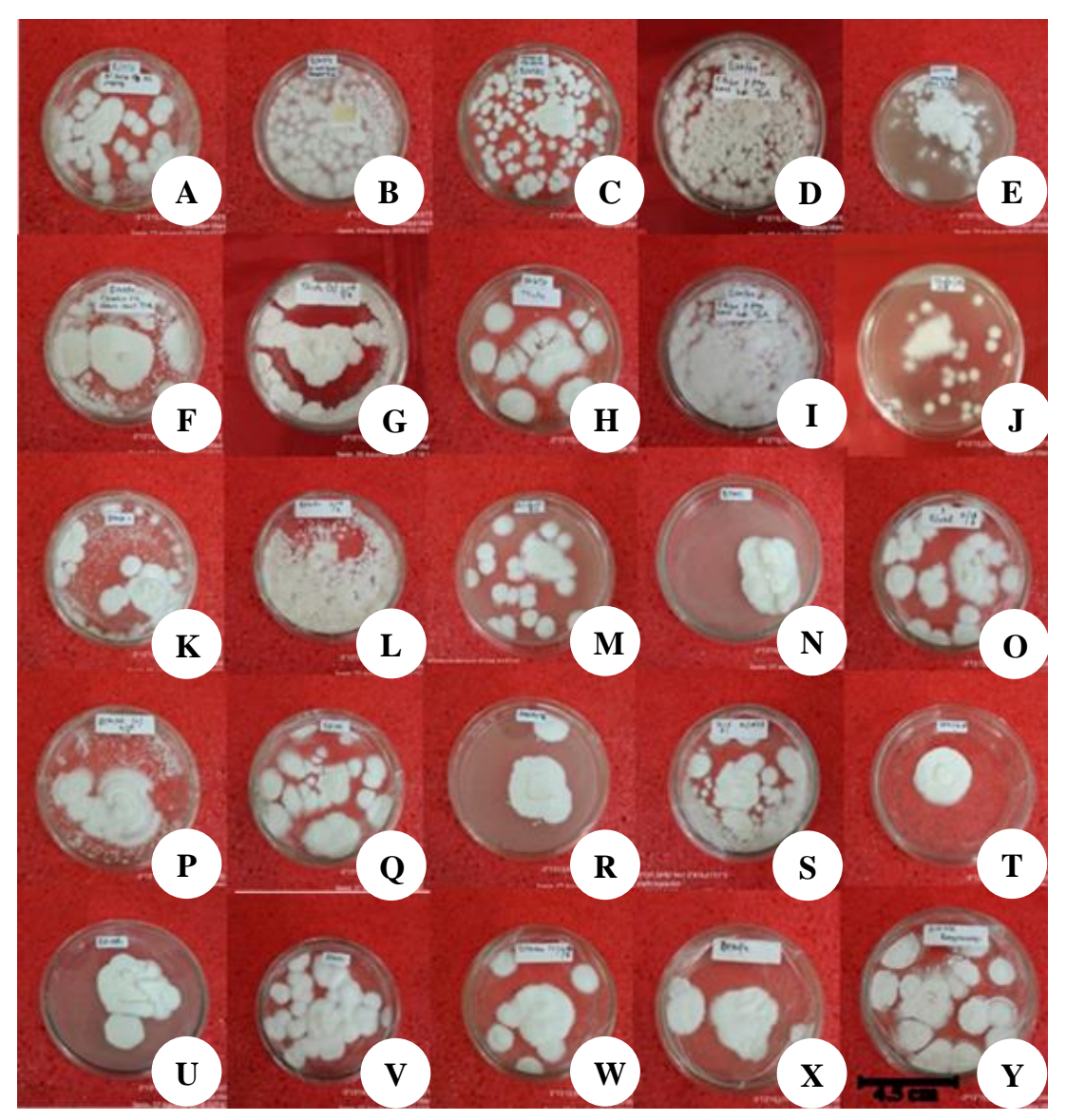

Figure 1. Beauveria bassiana isolates cultured in SDA media: BJgTs (A), BSmMs (B), BSwTd1 (C), BSwTd2 (D), BSwTd3 (E), BSwTd4 (F), BPdR (G), BKbTp (H), BKKPp2 (I), Ts1d3 (J), BTmPc (K), BTmTr (L), (M) Ts1d2 (M), BTmTs (N), BlePd2 (O), BTmKt (P), BPCmS (Q), BMkMs (R), BtmGa (S), BTmSr (T), BPcPd2 (U), BtmSo (V), BtmMa (W), BtmPe (X), Blepd (Y) 


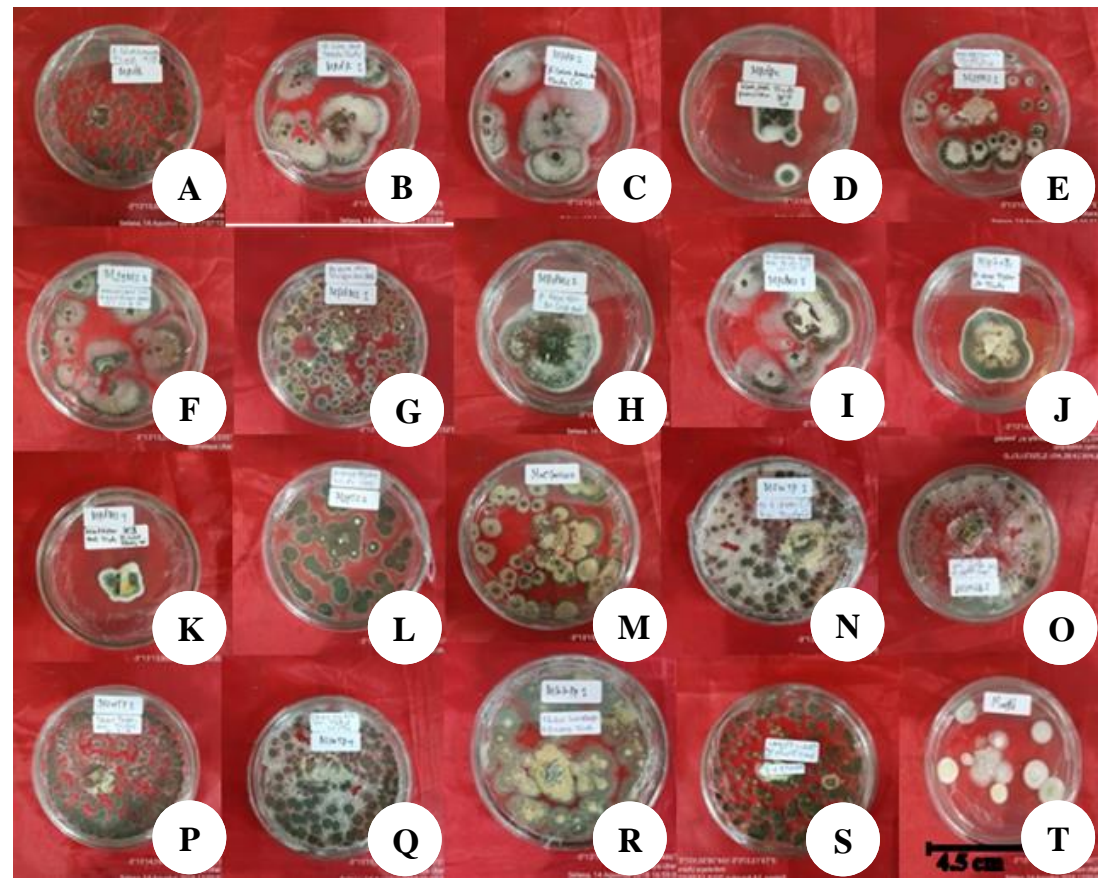

Figure 2. Metarhizium isolates cultured in SDA media: MPdB (A), MPdR1 (B), MPdR2 (C), MpdPe (D), MJgMs1 (E), MJgMs2 (F), MPdMs1 (G), MPdMs2 (H), MPdMs3 (I), MjgKeTs (J), MPdMs4 (K), MJgTs2 (L), MKbTp1 (M), MSwTp1 (N), MSwTp2 (O), MSwTp3 (P), MSwTp4 (Q), MKKPp1 (R), MKbTp2 (S), MagPd (T)

Table 1. Beauveria bassiana isolates from South Sumatra used in this research

\begin{tabular}{|c|c|c|}
\hline $\begin{array}{l}\text { Isolate } \\
\text { code }\end{array}$ & Isolate soil origin & $\begin{array}{l}\begin{array}{l}\text { Geographic } \\
\text { origin }\end{array} \\
\end{array}$ \\
\hline BJgTs & Tidal lowlands, maize & Telang Sari \\
\hline BSmMs & Tidal lowlands, watermelon & Mulya Sari \\
\hline BSwTd1 & Peatlands, oil palm & Talang Dabok \\
\hline BSwTd2 & Peatlands, oil palm & Talang Dabok \\
\hline BSwTd3 & Peatlands, oil palm & Talang Dabok \\
\hline BSwTd4 & Peatlands, oil palm & Talang Dabok \\
\hline BPdR & Freshwater swamps, paddy & Rambutan \\
\hline BKbTp & Highlands, cabbage & Talang Patai \\
\hline BKKPp2 & Highlands, rubber, and coffee & Pulau Pinang \\
\hline Ts1d3 & Peatlands & Talang Dabok \\
\hline $\mathrm{BTmPc}$ & Freshwater swamps & Indralaya \\
\hline $\mathrm{BTmTr}$ & Freshwater swamps & Telang Rejo \\
\hline Ts1d2 & Peatlands & Talang Dabok \\
\hline BTmTs & Highlands & Mulia Sari \\
\hline BlePd2 & Lipaphis erysimi & Pagardin \\
\hline BTmkt & Freshwater swamps & Kenten \\
\hline BPCmS & Pseudoplusia chalcites & Muara Siban \\
\hline BMkMs & Highlands & Muara Siban \\
\hline BtmGa & Freshwater swamps & Gandus \\
\hline $\mathrm{BTmSr}$ & Tidal lowlands & Srikaton \\
\hline $\mathrm{BPcPd} 2$ & Chrysodeixis chalcites & Pagardin \\
\hline BtmSo & Freshwater swamps & Soak \\
\hline BtmMa & Freshwater swamps & Mariana \\
\hline $\mathrm{BtmPe}$ & Freshwater swamps & Pemulutan \\
\hline Blepd & Lipaphis erysimi & Pagardin \\
\hline
\end{tabular}

Table 2. Metarhizium anisopliae isolates from South Sumatra used in this research

\begin{tabular}{lll}
\hline $\begin{array}{l}\text { Isolate } \\
\text { code }\end{array}$ & Isolate soil origin & $\begin{array}{l}\text { Geographic } \\
\text { origin }\end{array}$ \\
\hline MPdB & Freshwater swamps, paddy & $\begin{array}{l}\text { Banyuasin } \\
\text { Rambutan }\end{array}$ \\
MPdR1 & Freshwater swamps, paddy & Rambutan \\
MPdR2 & Freshwater swamps, paddy & Pemulutan \\
MpdPe & Freshwater swamps, paddy & Mulya Sari \\
MJgMs1 & Tidal lowlands, maize & Mulya Sari \\
MJgMs2 & Tidal lowlands, maize & Mulya Sari \\
MPdMs1 & Tidal lowlands, paddy & Mulya Sari \\
MPdMs2 & Tidal lowlands, paddy & Mulya Sari \\
MPdMs3 & Tidal lowlands, paddy & Telang Sari \\
MjgKeTs & Tidal lowlands, maize, and oil palm & Mulya Sari \\
MPdMs4 & Tidal lowlands, paddy & Telang Sari \\
MJgTs2 & Tidal lowlands, maize & Talang Patai \\
MKbTp1 & Highlands, cabbage & Talang Patai \\
MSwTp1 & Highlands, mustard & Talang Patai \\
MSwTp2 & Highlands, mustard & Talang Patai \\
MSwTp3 & Highlands, mustard & Talang Patai \\
MSwTp4 & Highlands, mustard & Pulau Pinang \\
MKKPp1 & Highlands, mustard, rubber, coffee & Talang Patai \\
MKbTp2 & Highlands, cabbage & Pagardin \\
\hline MagPd & Highlands, Aphis gossypii &
\end{tabular}




\section{Test insect preparation}

S. litura larvae were collected from the chili planting area in the experimental field of the Faculty of Agriculture, Sriwijaya University and farmers' vegetable fields which were not applied by synthetic insecticides. Then, the larvae were brought to the laboratory and maintained in a plastic cylinder whose upper part was covered with gauze (Ø 25 $\mathrm{cm}$, height $30 \mathrm{~cm}$ ) having been washed thoroughly using detergent. Next, water spinach plants were put into it for larvae feed.

Every day the larvae feed was replaced with fresh new feed. The larvae entering the pupae phase were transferred into a plastic cylinder $(\varnothing 10 \mathrm{~cm}$, height $15 \mathrm{~cm})$ with the top open and the bottom of the cylinder sprinkled with sifted soil and sterilized in an oven for 1 hour at $100^{\circ} \mathrm{C}$. The thickness of the soil inserted into the cylinder was $3 \mathrm{~cm}$. The plastic cylinder containing the pupae was put into a gauze cage $\left(30 \times 30 \times 30 \mathrm{~cm}^{3}\right)$ which had been chopped with chilies for laying eggs. Adults arising from the pupae were fed with honey smeared on cotton and hung over a cage. The hatched eggs were transferred into a plastic cylinder and fed with water spinach which was replaced every day. The larvae used for toxicity testing were the second instar of the third offspring or afterward.

\section{Culture filtrate production}

All isolates before being filtered were first made fit by modifying the method of Herlinda (2010). The media for making fit used Sabouraud Dextrose Agar (SDA, Merck) as much as $16.2 \mathrm{~g}$ and added $250 \mathrm{~mL}$ aquadest enriched with $1.25 \mathrm{~g}$ Tenebrio molitor larvae flour (5 g). After that, the ingredients were mixed and stirred evenly and then put in an Erlenmeyer (size $250 \mathrm{~mL}$ ), sterilized in an autoclave for 120 minutes at a pressure of $1 \mathrm{~atm}$. The media was poured into the Petri dish as much as $10 \mathrm{~mL}(\varnothing 9 \mathrm{~cm})$ in aseptic laminar flow air conditions. Then, the entomopathogenic fungi isolates were inoculated in the SDA media and incubated for 14 days.

Isolates of entomopathogenic fungi derived from SDA media of aged 14 days were then transferred and grown into liquid media (broth media), PDB (Potato Dextrose Broth) prepared as follows: the PDB media composition consisting of $20 \mathrm{~g}$ dextrose monohydrate, $200 \mathrm{~g}$ potatoes, and $1000 \mathrm{~mL}$ aquadest. Before the potatoes were extracted, they were cut into cubes with a size of $\pm 2 \times 2 \times 2 \mathrm{~cm}^{3}$ and boiled using $1000 \mathrm{~mL}$ aquadest for 20 minutes. This PDB medium was sterilized in the autoclave and after it got cold, the entomopathogenic fungus isolates were inoculated into it. This liquid culture was incubated for 6 weeks.

After the fungus liquid culture (fungal broth) was 6 weeks old, the fungus filtration is carried out. The filtration was conducted in two stages, namely filtering using filter paper and syringe filter. In the first stage, $100 \mathrm{~mL}$ of 6week-old fungal broth was filtered using Whatman filter paper no. 42 and coated with a thickness of $1 \mathrm{~cm}$ cotton. The culture filtrate obtained from the first stage of filtering was then sucked up to $10 \mathrm{~mL}$ using a hypodermic needle (spike). Then, the needle was removed and the base of the needle was fitted with a syringe filter $(0.45 \mu \mathrm{m}-25 \mathrm{~mm})$. The $10 \mathrm{~mL}$ spike was pressed so that it released culture filtrate from the syringe filter. The $100 \mathrm{~mL}$ of fungal broth produced $\pm 70 \mathrm{~mL}$ of culture filtrate. The culture filtrate was taken as much as $1 \mathrm{~mL}$ to be dripped on a piece of chili leaf which was used as a toxicity test. This culture filtrate is often referred to as raw secondary metabolites (Soesanto et al. 2019). To ensure the culture filtrate did not contain propagules (hyphae, mycelia) and conidia, it was grown on agar media (SDA) before it was applied. If it does not grow fungus on the SDA media, the culture filtrate can be applied.

\section{Insecticidal activity test of entomopathogenic fungus culture filtrate}

The chili leaves that had been dropped by the culture filtrate were first drained; before $25 \mathrm{~S}$. litura larvae were fasted for 2 hours, and then put into them. The second instar larvae were left to eat leaves that had been dropped with culture filtrate for 6 hours. After 6 hours, the larvae were transferred into a plastic cylinder topped with gauze (Ø $25 \mathrm{~cm}$, height $30 \mathrm{~cm}$ ) containing 15-30 clean chili leaves which were not dripped with culture filtrate. Every day the chili leaves were replaced with the new ones. Every day the dead larvae were recorded up to 12 days after the application.

\section{Data analysis}

The differences in mortality data and lethal time that killed $50 \%$ of test insects $\left(\mathrm{LT}_{50}\right)$ were analyzed using analysis of variance (ANOVA), after that further tests were carried out using the 5\% Tukey's Honestly Significant Difference (HSD). All data were calculated using software of SAS University Edition 2.7 9.4 M5.

\section{RESULTS AND DISCUSSION}

\section{Insecticidal activities of entomopathogenic fungi}

The culture filtrate derived from twenty-five $B$. bassiana isolates tested for the insecticidal activity showed that the most toxic $B$. bassiana isolates were those coded BJgTs (98\%) and were not significantly different, among others with BSwTd2 (94.67\%) and BTmTs isolates (96\%). All B. bassiana isolates showed the ability to kill the test larvae (Table 3). The BJgTs, BSwTd2, and BTmTs isolates were the most toxic because they produced the highest mortality and also their ability to kill the shortest as evidenced by the short $\operatorname{LT}_{50}(6.35,5.92$, and 7.78 days $)$ isolates. The most toxic isolates were shown with the highest mortality and their shortest $\mathrm{LT}_{50}$. Consequently, for B. bassiana, the most toxic isolate was BSwTd2.

The culture filtrate of the twenty M. anisopliae isolates which were tested for their insecticidal activity showed that the most toxic isolates were that coded MKbTp2 (96\%) and MPdB (85.33\%) and the mortality of both isolates was significantly different from the other isolates (Table 4). The BSwTd2 isolate was the most toxic because they produced the highest mortality as well as the ability to kill the shortest as evidenced by the shortest $\mathrm{LT}_{50}$ (7.36 days), and then followed by $\mathrm{LT}_{50}$ isolate MPdB (8.09 days). The most 
toxic $M$. anisopliae isolate was proven by the highest mortality and the shortest $\mathrm{LT}_{50}$ which was $\mathrm{MKbTp} 2$ isolate.

The color of the fungal broth (Figure 3) and culture filtrate (Figure 4) of B. bassiana varied among the isolates. All fungal broth isolates were generally transplanted brown, but there were among those isolates dark brown in color, for example, isolates BSwTd2, BSwTd3, BPdR, TS1d2. There was a tendency for the darker color of the fungal broth and culture filtrate to cause higher mortality. The color of fungal broth (Figure 5) and culture filtrate (Figure 6) of $M$. anisopliae differed from the colors of fungal broth and culture of B. bassiana. The M. anisopliae fungal broth was generally dark greenish-brown, but the culture filtrate tended to have a more varied color, from greenish dark brown to light brown. The same tendency was also produced in $M$. anisopliae isolates, i.e., the color of the older culture filtrate resulting in higher mortality. The isolates having a darker colored culture filtrate were MPdB, MPdMs1, MPdMs2, MPdMs3, MKbTp1, MKbTp2.

Table 3. Mortality of larval Spodoptera litura after being infested with Beauveria bassiana culture filtrates

\begin{tabular}{lll}
\hline Isolate codes & Mortality \pm SE*$^{*}(\boldsymbol{\%})$ & LT $_{\mathbf{5 0}}$ (days) \pm SE \\
\hline BJgTs & $98.00 \pm 1.41^{\mathrm{b}}$ & $6.35 \pm 0.49$ \\
BSmMs & $50.00 \pm 32.53^{\mathrm{ab}}$ & $11.57 \pm 4.08$ \\
BSwTd1 & $49.33 \pm 15.36^{\mathrm{ab}}$ & $12.03 \pm 3.52$ \\
BSwTd2 & $94.67 \pm 4.35^{\mathrm{ab}}$ & $5.92 \pm 0.46$ \\
BSwTd3 & $73.33 \pm 18.51^{\mathrm{ab}}$ & $8.86 \pm 1.78$ \\
BSwTd4 & $26.00 \pm 1.41^{\mathrm{ab}}$ & $16.07 \pm 0.97$ \\
BPdR & $86.67 \pm 3.93^{\mathrm{ab}}$ & $8.17 \pm 0.61$ \\
BKbTp & $62.67 \pm 10.39^{\mathrm{ab}}$ & $10.71 \pm 0.91$ \\
BKKPp2 & $58.00 \pm 7.07^{\mathrm{ab}}$ & $10.68 \pm 0.34$ \\
TS1d3 & $10.67 \pm 2.88^{\mathrm{a}}$ & $17.45 \pm 0.76$ \\
BTmPc & $46.67 \pm 17.01^{\mathrm{ab}}$ & $14.32 \pm 3.72$ \\
BTmTr & $29.33 \pm 9.68^{\mathrm{ab}}$ & $14.31 \pm 1.79$ \\
TS1d2 & $88.00 \pm 8.22^{\mathrm{ab}}$ & $7.87 \pm 1.11$ \\
BTmTs & $96.00 \pm 0.00^{\mathrm{ab}}$ & $7.78 \pm 0.09$ \\
BLePd2 & $70.00 \pm 21.21^{\mathrm{ab}}$ & $9.59 \pm 1.43$ \\
BTmKt & $80.00 \pm 14.73^{\mathrm{ab}}$ & $8.80 \pm 1.41$ \\
BPcMs & $81.33 \pm 9.49^{\mathrm{ab}}$ & $7.87 \pm 1.32$ \\
BMkMs & $72.00 \pm 17.99^{\mathrm{ab}}$ & $10.82 \pm 2.46$ \\
BTmGa & $66.67 \pm 22.34^{\mathrm{ab}}$ & $12.27 \pm 3.60$ \\
BTmSr & $21.33 \pm 9.30^{\mathrm{ab}}$ & $16.80 \pm 2.67$ \\
BPcPd2 & $18.67 \pm 7.85^{\mathrm{ab}}$ & $9.43 \pm 3.86$ \\
BTmSo & $80.00 \pm 14.14^{\mathrm{ab}}$ & $7.55 \pm 1.35$ \\
BTmMa & $52.00 \pm 19.69^{\mathrm{ab}}$ & $11.09 \pm 1.62$ \\
BTmPe & $70.00 \pm 18.38^{\mathrm{ab}}$ & $9.30 \pm 1.94$ \\
BLePd & $94.00 \pm 4.24^{\mathrm{ab}}$ & $9.30 \pm 0.45$ \\
ANOVA F-value & $2.09^{*}$ & $1.20^{\mathrm{n}}$ \\
P value $(0.05)$ & 0.02 & 0.30 \\
Tukey's HSD test & 67.09 & - \\
\hline No: & &
\end{tabular}

Note: $\mathrm{ns}=$ not significantly different; $*$ = significantly different; values within a column (the data of each isolate) followed by the same letters were not significantly different at $\mathrm{P}<0.05$ according to Tukey's HSD test. Original data were transformed using Arcsin transformation prior to statistical analysis

\section{Effect of entomopathogenic fungal culture filtrate on test larvae}

Spodoptera litura larvae fed with chili leaves applied with B. bassiana or M. anisopliae culture filtrate exhibited the same behavior, i.e., they increasingly ate less, while the controls not given culture filtrate continued to eat greedily. The chili leaves given to the larvae which were not given culture filtrate generally only left a leaf bone, whereas in the larvae given culture filtrate there were still leaves remaining (Figures 7 and 8). Thus, the culture filtrate could reduce the appetite of $S$. litura larvae.

The larvae $S$. litura has given culture filtrate besides being lazier to eat showed lazier and lazier to move. After 2 and 3 days being given the culture filtrate, the larvae began to change the color of integument which was previously bright green to become dull and the larvae were discovered to be dead. Four days after being given the culture filtrate, the larvae increasingly began to shrink and die. The dead larvae were wrinkled, dry, black, and odorless. The larvae not given the culture filtrate had larger body sizes and the integument colors were greener, and brighter (Figures 9 and 10).

Table 4. Mortality of larval Spodoptera litura after being infested with Metarhizium anisopliae culture filtrates

\begin{tabular}{lll}
\hline Isolate codes & Mortality \pm SE*(\%) & LT $_{\mathbf{5 0}}$ (days) \pm SE \\
\hline MPdB & $85.33 \pm 14.67^{\mathrm{b}}$ & $8.09 \pm 1.88^{\mathrm{a}}$ \\
MPdR1 & $57.33 \pm 19.37^{\mathrm{ab}}$ & $11.87 \pm 2.56^{\mathrm{a}}$ \\
MPdR2 & $65.33 \pm 13.33^{\mathrm{ab}}$ & $10.43 \pm 0.51^{\mathrm{a}}$ \\
MPdPe & $42.67 \pm 9.61^{\mathrm{ab}}$ & $12.67 \pm 0.89^{\mathrm{a}}$ \\
MJgMs1 & $53.33 \pm 23.25^{\mathrm{ab}}$ & $13.67 \pm 4.52^{\mathrm{a}}$ \\
MJgMs2 & $25.33 \pm 3.53^{\mathrm{ab}}$ & $14.50 \pm 0.56^{\mathrm{a}}$ \\
MPdMs1 & $73.33 \pm 10.41^{\mathrm{ab}}$ & $9.90 \pm 0.97^{\mathrm{a}}$ \\
MPdMs2 & $84.00 \pm 9.24^{\mathrm{ab}}$ & $8.70 \pm 1.26^{\mathrm{a}}$ \\
MPdMs3 & $68.00 \pm 16.17^{\mathrm{ab}}$ & $10.08 \pm 0.86^{\mathrm{a}}$ \\
MJgKeTs & $42.67 \pm 10.67^{\mathrm{ab}}$ & $12.68 \pm 1.05^{\mathrm{a}}$ \\
MPdMs4 & $16.00 \pm 10.07^{\mathrm{ab}}$ & $53.70 \pm 23.11^{\mathrm{b}}$ \\
MJgTs2 & $46.67 \pm 13.92^{\mathrm{ab}}$ & $14.29 \pm 2.23^{\mathrm{a}}$ \\
MKbTp1 & $84.00 \pm 10.07^{\mathrm{ab}}$ & $8.69 \pm 0.95^{\mathrm{a}}$ \\
MSwTp1 & $56.00 \pm 12.22^{\mathrm{ab}}$ & $14.64 \pm 3.24^{\mathrm{a}}$ \\
MSwTp2 & $74.67 \pm 13.92^{\mathrm{ab}}$ & $10.62 \pm 1.39^{\mathrm{a}}$ \\
MSwTp3 & $61.33 \pm 16.38^{\mathrm{ab}}$ & $10.91 \pm 1.99^{\mathrm{a}}$ \\
MSwTp4 & $61.33 \pm 23.13^{\mathrm{ab}}$ & $14.60 \pm 5.54^{\mathrm{a}}$ \\
MKKPp1 & $44.00 \pm 10.07^{\mathrm{ab}}$ & $12.33 \pm 0.90^{\mathrm{a}}$ \\
MKbTp2 & $96.00 \pm 4.00^{\mathrm{b}}$ & $7.36 \pm 0.62^{\mathrm{a}}$ \\
MagPd & $33.33 \pm 3.53^{\mathrm{ab}}$ & $12.98 \pm 0.23^{\mathrm{a}}$ \\
ANOVA F-value & $2.39^{*}$ & $50.13^{*}$ \\
P value $(0.05)$ & 0.01 & 0.00 \\
Tukey's HSD test & 53.35 & 2.65 \\
\hline No: ns not &
\end{tabular}

Note: $\mathrm{ns}=$ not significantly different; $*$ = significantly different; values within a column (the data of each isolate) followed by the same letters were not significantly different at $\mathrm{P}<0.05$ according to Tukey's HSD test. Original data were transformed using Arcsin transformation prior to statistical analysis 


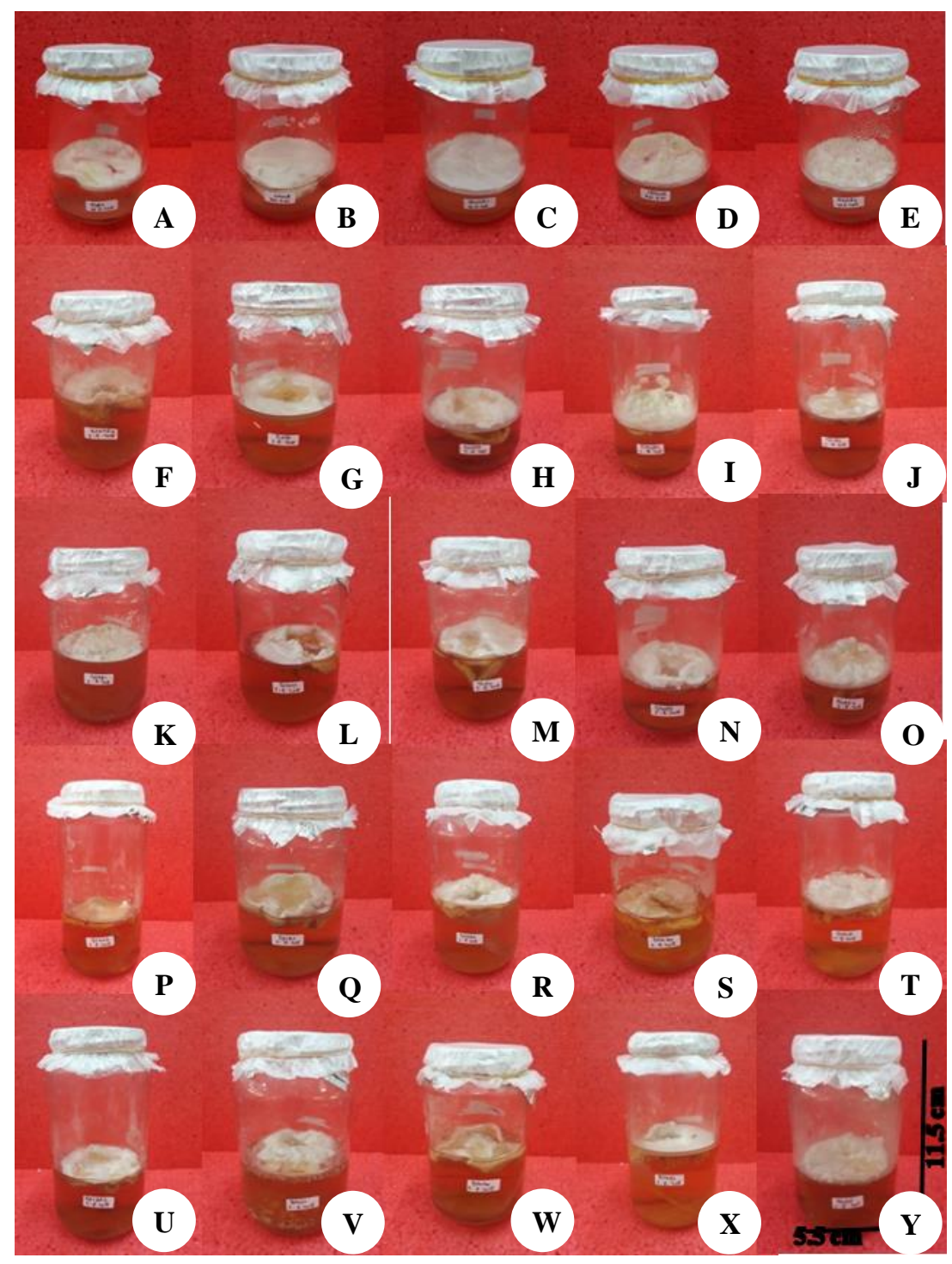

Figure 3. Beauveria bassiana isolates cultured in PDB: BJgTs (A), BSmMs (B), BSwTd1 (C), BSwTd2 (D), BSwTd3 (E), BSwTd4 (F), BPdR (G), BKbTp (H), BKKPp2 (I), Ts1d3 (J), BTmPc (K), BTmTr (L), (M) Ts1d2 (M), BTmTs (N), BlePd2 (O), BTmKt (P), BPCmS (Q), BMkMs (R), BtmGa (S), BTmSr (T), BPcPd2 (U), BtmSo (V), BtmMa (W), BtmPe (X), Blepd (Y)

\section{Discussion}

The $B$. bassiana culture filtrate, particularly the isolates coded BSwTd2, were the most toxic compared to other isolates with $\mathrm{LT}_{50}$ of only 5.91 days. The BSwTd2 isolate was from peat soils overgrown with oil palm plants. For $M$. anisopliae, the most toxic MKbTp2 isolate was from the cabbage in highland. The larvae began to die after $3 \times 24$ hours after the treatment either due to $B$. bassiana or $M$. anisopliae. The larvae death resulted from the 6 weeks of incubation of entomopathogenic fungi causing the toxic culture filtrate. According to Pinnamaneni et al. (2010), the culture of filtrates of the toxic B. bassiana was caused by the incubation in liquid culture media in which the fungus produced chitinolytic exochitinase enzymes so that when they entered the body the insect was able to degrade the cuticle. In addition, the fungal broth during the incubation could produce protease enzymes (Qazi 2008).
The time of death of the larvae by this culture filtrate was faster than that of by conidia. El Husseini (2019) stated that the death of Spodoptera larvae by M. anisopliae conidia began to occur at the fourth day (4x24 hours) or the fifth day after the treatment (post-treatment), whereas in this study the $M$. anisopliae culture filtrate began to kill $S$. litura at the third day after the treatment. The lethal time difference between these was due to the mode of action of fungal conidia being different from the culture filtrate. To kill the host insect, the fungus conidia got contact first with it and then produced toxins to kill the host, while the culture filtrate directly killed the host insect. El-Ghany (2015) states that entomopathogenic fungus conidia kill its host insect in two stages: parasitic and saprophytic phases. The parasitic phase began with the fungal conidia attaching to the host insect cuticle (Augustyniuk-Kram and Kram 2012). Then, if the humidity was high, the conidia started to germinate on the host cuticle (El-Ghany 2015). The 
conidia germinating by forming germ tubes continued to grow sticking out to find a soft integument position to facilitate entry into the cuticle (Fernandes et al. 2007). The infection occurs when the germ tubes are able to penetrate insect cuticles and the ability to infect them is a determining factor for the fungus virulence (Altre and Vandenberg 2001). After the germ, tubes penetrated the cuticle and reached the hemocoel, and then they produced specific infection hyphae originating at appressoria (ElGhany 2015). Furthermore, the hyphae spread to the hemolymph and developed to produce blastospores, and the blastospores produced fungal cytotoxic, for example, destruxins by $M$. anisopliae which killed the host insects
(Mancillas-Paredes et al. 2019), but the death of these host insects was not caused only by the toxin but also due to the mechanical damage by the penetration of fungi into the body of insects (El-Ghany 2015).

After the host insect died, it entered into the saprophytic phase which was influenced by favorable environmental conditions (Peña-Peña et al. 2015). In the body of the dead insect, the fungus formed mycelia and hyphae which continued to grow covering the body of the host insect, and then the hyphae formed conidiogenous cells and the conidia were produced by utilizing the nutrients/fluids of the host insect and finally, the infection process was complete (El-Ghany 2015).

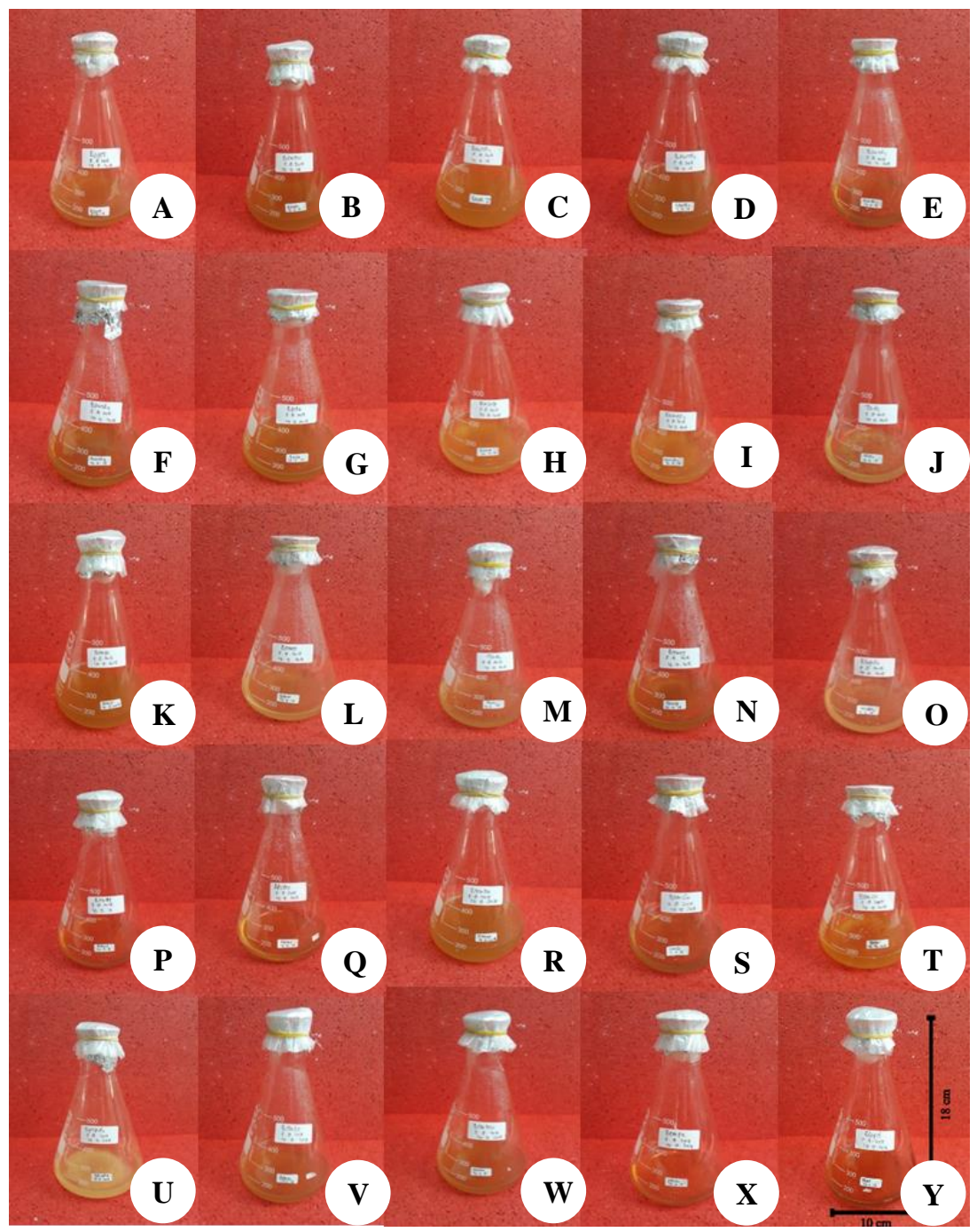

Figure 4. Beauveria bassiana culture filtrate: BJgTs (A), BSmMs (B), BSwTd1 (C), BSwTd2 (D), BSwTd3 (E), BSwTd4 (F), BPdR (G), BKbTp (H), BKKPp2 (I), Ts1d3 (J), BTmPc (K), BTmTr (L), (M) Ts1d2 (M), BTmTs (N), BlePd2 (O), BTmKt (P), BPCmS (Q), BMkMs (R), BtmGa (S), BTmSr (T), BPcPd2 (U), BtmSo (V), BtmMa (W), BtmPe (X), Blepd (Y) 
In contrast to the mode of action of fungal conidia, a fungal culture filtrate directly kills the host insect due to the toxins produced by fungal broth so that the time needed to kill the host insect is shorter. The entomopathogenic fungus cultured in liquid media can produce conidia in the form of blastospores (Mascarin et al. 2015) which can produce toxins (Mascarin and Jaronski 2016). In this study, the result of calculating conidia density after being incubated for 6 weeks was generally more than $1 \times 10^{9}$ conidia $\mathrm{mL}^{-1}$. Fungal conidia and propagules were separated from the filtrate through two stages of filtration to produce toxic fungal culture filtrate. The $B$. bassiana and $M$. anisopliae culture filtrates were able to kill up to $94.67 \%$ and $96 \%$ of the larvae of $S$. litura, respectively. The short time of death by this culture filtrate resulted from the death of the direct host insect by consuming feed (chili leaves) moistened with the culture filtrate. Soesanto et al. (2019) stated that entomopathogenic fungal culture filtrate contains secondary metabolites. B. bassiana culture filtrate containing the secondary metabolites can weaken the host insect's immune system (Zibaee et al. 2011). The secondary metabolites produce toxins, for example, destruxins and efrapeptins (Zibaee et al. 2009). B. bassiana also produces a protease enzyme that can kill host insects by dissolving their body proteins (Mancillas-Paredes et al. 2019).

The color of fungal broth and culture of B. bassiana and $M$. anisopliae varied between isolates. The darker color of fungal broths and culture filtrates tend to cause higher mortality. In line with the results obtained by Ayudya et al. (2019), the darker culture filtrates tended to be more toxic than the light-colored ones. The darker culture filtrates show higher production of secondary metabolites (Luo et al. 2017) and the activity of extracellular enzymes (Khachatourians et al. 2007) and the enzymes produced such as proteases are able to dissolve integument insects that result in death (Mancillas-Paredes et al. 2019).

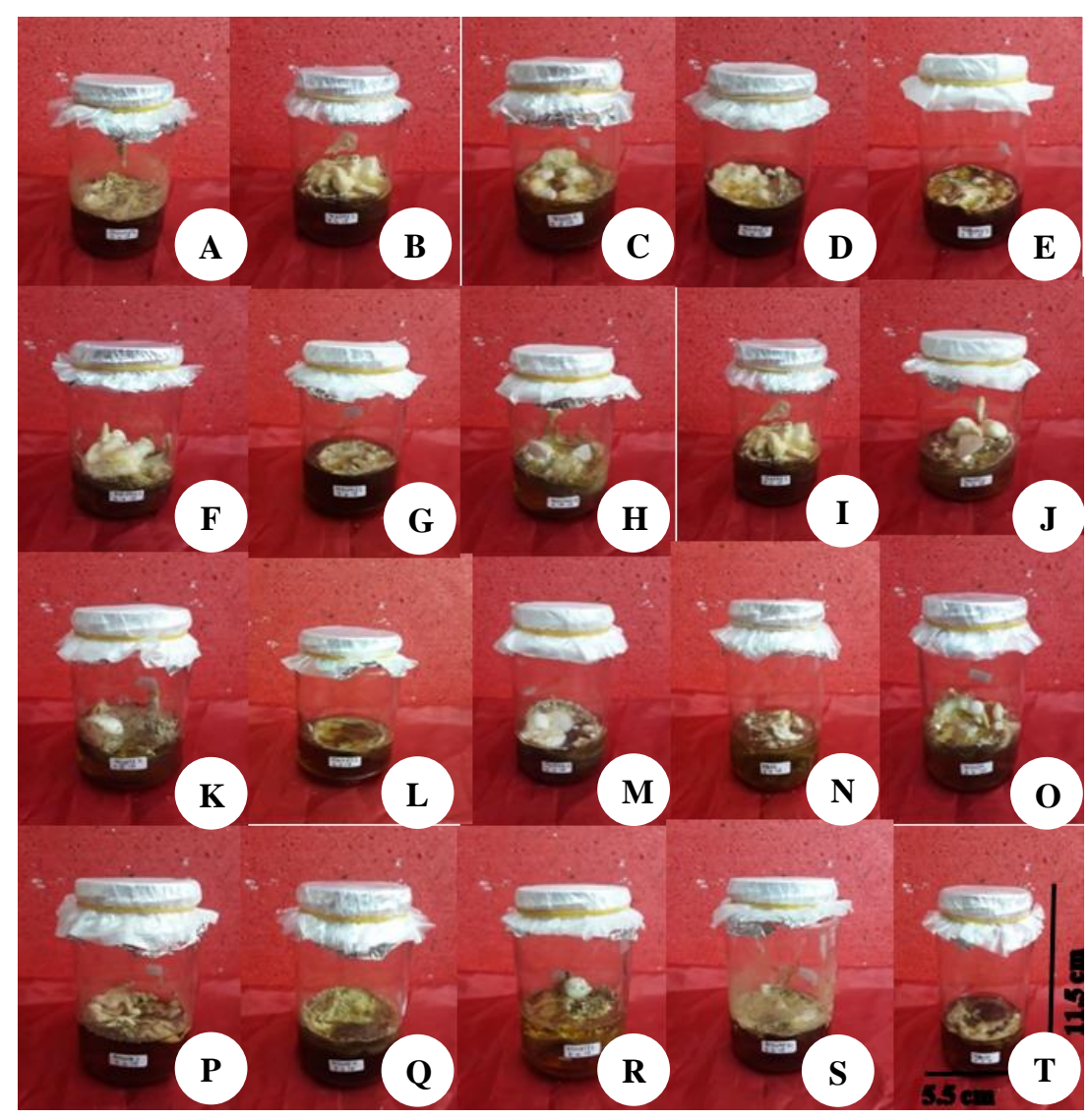

Figure 5. Metarhizium anisopliae isolates cultured in PDB: MPdB (A), MPdR1 (B), MPdR2 (C), MpdPe (D), MJgMs1 (E), MJgMs2 (F), MPdMs1 (G), MPdMs2 (H), MPdMs3 (I), MjgKeTs (J), MPdMs4 (K), MJgTs2 (L), MKbTp1 (M), MSwTp1 (N), MSwTp2 (O), MSwTp3 (P), MSwTp4 (Q), MKKPp1 (R), MKbTp2 (S), MagPd (T) 


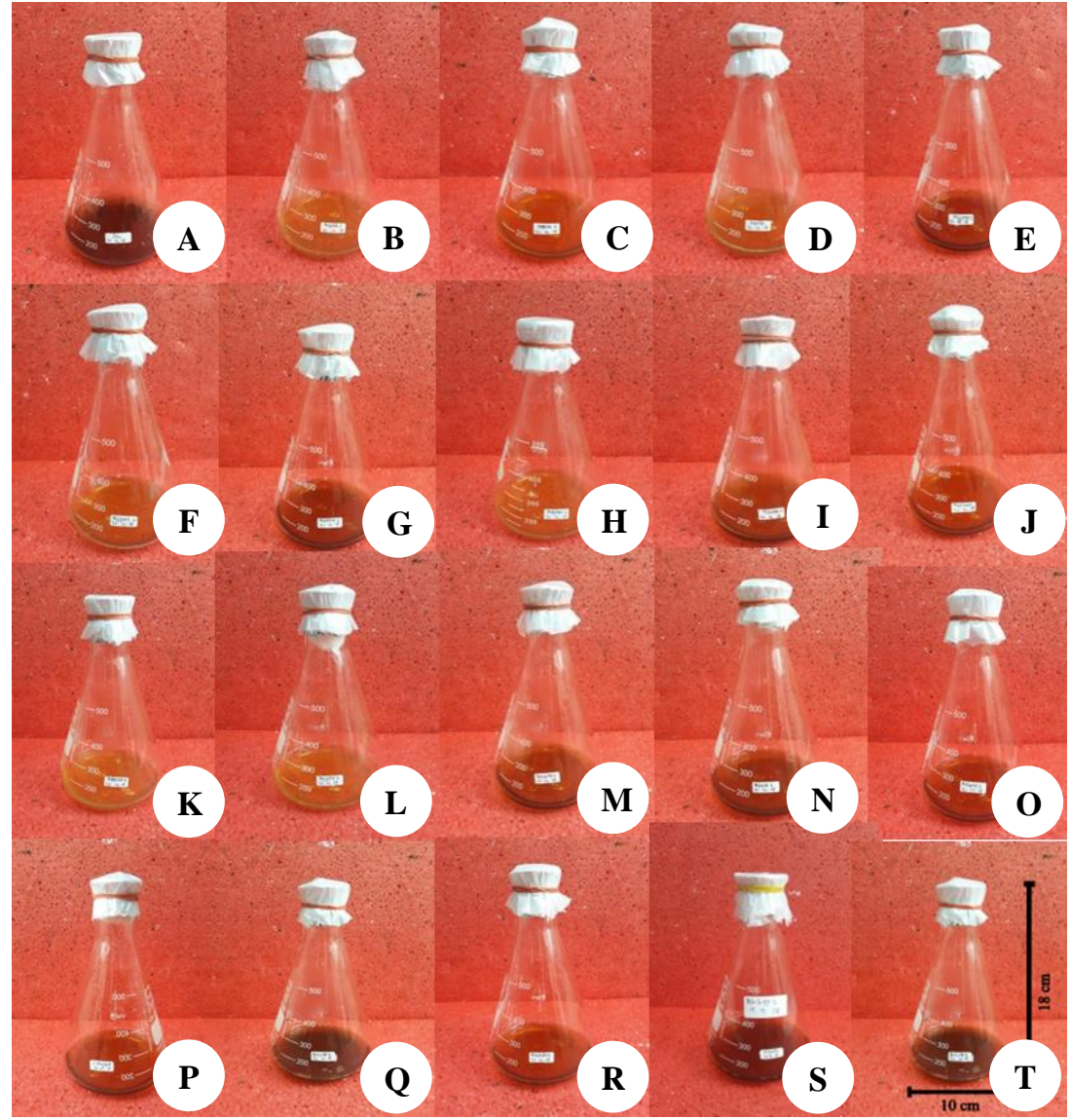

Figure 6. Metarhizium anisopliae culture filtrate: MPdB (A), MPdR1 (B), MPdR2 (C), MpdPe (D), MJgMs1 (E), MJgMs2 (F), MPdMs1 (G), MPdMs2 (H), MPdMs3 (I), MjgKeTs (J), MPdMs4 (K), MJgTs2 (L), MKbTp1 (M), MSwTp1 (N), MSwTp2 (O), MSwTp3 (P), MSwTp4 (Q), MKKPp1 (R), MKbTp2 (S), MagPd (T)

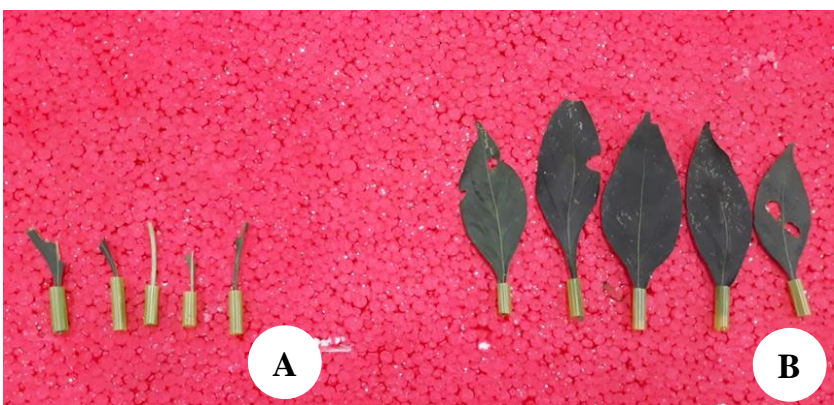

Figure 7. The leaf damage: control (A) and larval Spodoptera litura applied with Beauveria bassiana culture filtrate (B)

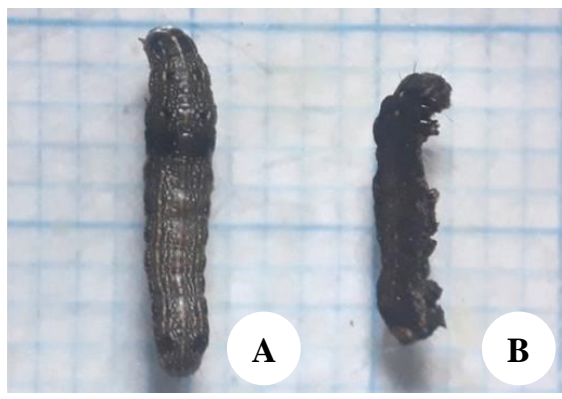

Figure 9. The healthy (A) and dead larvae (B) of Spodoptera litura caused by Beauveria bassiana culture filtrate

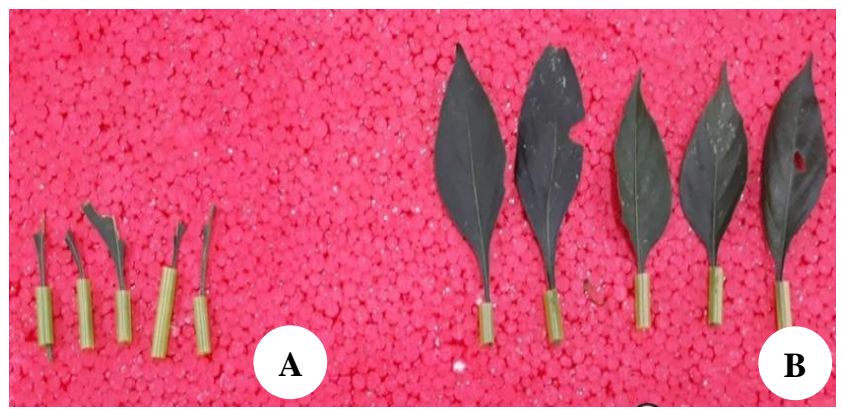

Figure 8. The leaf damage: control (A) and larval Spodoptera litura applied with Metarhizium anisopliae culture filtrate (B)

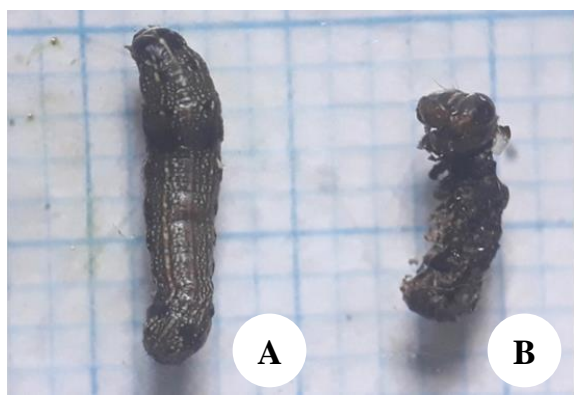

Figure 10. The healthy (A) and dead larvae (B) of Spodoptera litura caused by Metarhizium anisopliae culture filtrate 
The symptoms of sick host insects by culture filtrate in this study differed from the deaths by fungal conidia. The insects getting sick by the culture filtrate were not covered by mycelia or conidia on the integument. However, they got sick because of the fungal conidia infection which was generally covered in mycelia (Sumikarsih et al. 2019). The body shape of the sick $S$. litura larvae due to the culture filtrate was shrunk, wrinkled, dry, and odorless. Similar to the results of the study of Ayudya et al. (2019), the S litura larvae treated with $B$. bassiana culture filtrate decreased their body weight and became dried, odorless, and the integument was not overgrown with fungal mycelia because in the culture filtrate it no longer contained conidia but contained toxic compounds for host insects. Therefore, the mortality of $S$. litura larvae in this study was caused by the culture filtrate containing toxic compounds. Zibaee et al. (2011) state that toxic compounds in the culture filtrate are secondary metabolites. Zibaee et al. (2009) stated that the secondary metabolites are easier to apply in the field because they can be integrated with other control techniques including synthetic insecticides. Consequently, the culture filtrate which is toxic due to the high content of secondary metabolites has the potential to be further developed for 'the active ingredient of mycoinsecticide.

The most toxic isolates of the culture filtrate were BSwTd2 of B. bassiana and MKbTp2 of M. anisopliae resulting in the mortality of above $90 \%$. The two isolates that were found each came from the lowlands and highlands so that in the future there is an opportunity for the isolates to be developed and applied in low and highland ecosystems. Entomopathogenic fungi that produce toxic filtrate cultures are capable of killing their hosts in a short time, so that they have the potential to be active ingredients in the development of mycoinsecticides technology.

\section{ACKNOWLEDGEMENTS}

Thank you to the sponsors of the donors of this research, the Individual National Strategic Research (PSNI) program for the 2018 fiscal year based on the Research Contracts of the Directorate of Research and Community Service (DRPM), Directorate General of Research and Development Strengthening, Ministry of Technology Research and Higher Education, Contract number: 093/SP2H/LT/DRPM/IV/2018 chaired by SH.

\section{REFERENCES}

Altre JA, Vandenberg JD. 2001. Factors influencing the infectivity of isolates of Paecilomyces fumosoroseus against diamondback moth, Plutella xylostella. J Invertebr Pathol 78: 31-36. DOI: 10.1006/jipa.2001.5043

Augustyniuk-Kram A, Kram KJ. 2012. Entomopathogenic fungi as an important natural regulator of insect outbreaks in forests review. Forest Ecosystem, More than Just Trees. In: Blanco JA. (ed.). In Tech, Croatia. DOI: 10.5772/30596.

Ayudya D, Herlinda S, Suwandi S. 2019. Insecticidal activity of culture filtrates from liquid medium of Beauveria bassiana isolates from South Sumatra (Indonesia) wetland soil against larvae of Spodoptera litura. Biodiversitas 20: 2101-2109. DOI: 10.13057/biodiv/d200802
Bandani AR, Khambay BPS, Faull L, Newton R, Deadman M, Butt TM. 2000. Production of efrapeptins by Tolypocladium species and evaluation of their insecticidal and antimicrobial properties. Mycol Res 104: 537-544. DOI: 10.1017/S0953756299001859.

Bueno RC, Bueno AF, Moscardi F, Parra JR, Hoffmanncampo CB. 2011. Lepidopteran larva consumption of soybean foliage: basis for developing multiple-species economic thresholds for pest management decisions. Pest Manag Sci 67 (2): 170-174

Darlan N, Pradiko I, Winarna, Siregar HH. 2016. Effect of el niño 2015 on oil palm performance in central and Southern Sumatera. J Tanah dan Iklim 40: 113-120. DOI: 10.2017/jti.v40n2.2016.113-120. [Indonesian]

El-Ghany TMA. 2015. Entomopathogenic Fungi and their Role in Biological Control. Biology Department Faculty of Science Jazan University KSA, Cairo. DOI:10.4172/978-1-63278-065-2-66

El-Husseini MMM. 2019. Efficacy of the entomopathogenic fungus, Metarhizium anisopliae (Metsch.), against larvae of the cotton leafworm, Spodoptera littoralis (Boisd.) (Lepidoptera: Noctuidae), under laboratory conditions. Egypt J Biol Pest Control 29: 4-6. DOI: 10.1186/s41938-019-0156-2

Fattah A, Syam S, Daud ID, Dewi VS, Rahman A. 2018. The intensity of leaf damage caused by attack of Spodoptera litura F and seed yield on some soybean varieties in South Sulawesi Indonesia. Sci Res J 6: 5560 .

Fernandes EKK, Rangel DEN, Moraes AM, Bittencourt VREP, Roberts DW. 2007. Variability in tolerance to UV-B radiation among Beauveria spp. isolates. J Invertebr Pathol 96: 237-243. DOI: 10.1016/j.jip.2007.05.007

Garrido-Jurado J, Torrent J, Barrón V, Corpas A, Quesada-Moraga E. 2011. Soil properties affect the availability, movement, and virulence of entomopathogenic fungi conidia against puparia of Ceratitis capitata (Diptera: Tephritidae). Biol Control 58: 277-285. DOI: 10.1016/j.biocontrol.2011.05.017

Herlinda S, Yudha S, Thalib R, Khodijah, Suwandi, Lakitan B, Verawaty M. 2018a. Species richness and abundance of spiders inhabiting rice in fresh swamps and tidal lowlands in South Sumatera, Indonesia. J ISSAAS 24: 82-93.

Herlinda S, Rizkie L, Suwandi, Susilawati, Lakitan B, Verawaty M, Hasbi. 2018b. Effects of high temperature and ultraviolet-C irradiance on conidial viability and density of Beauveria bassiana and Metarhizium anisopliae isolated from soils of lowland ecosystems in Indonesia. Eurasian J Anal Chem 13: 209-216.

Johari A, Herlinda S, Pujiastuti Y, Irsan C, Sartiami, D. 2016. Morphological and genetic variation of Thrips parvispinus (Thysanoptera: Thripidae) in chili plantation (Capsicum annuum L.) in the lowland and highland of Jambi Province, Indonesia. Am J Biol Sci 2: 17-21. DOI: 10.11648/j.ajbio.s.2014020601.14

Juhriah, Azrai M, Tambaru E, Rahayu JE. 2019. Phenotypic characteristics and grouping of hybrid waxy corn Zea mays L. J Ilmu Alam dan Lingkungan 10: 51-60. DOI: 10.20956/jal.v10i1.6624 [Indonesian]

Karenina T, Herlinda S, Irsan C, Pujiastuti Y. 2019. Abundance and species diversity of predatory arthropods inhabiting rice of refuge habitats and synthetic insecticide application in freshwater swamps in South Sumatra, Indonesia. Biodiversitas 20 (8): 2375-2387. DOI: $10.13057 /$ biodiv/d200836

Kartika K, Lakitan B, Wijaya A, Kadir S, Widuri L.I, Siaga E. 2018. Effects of particle size and application rate of rice-husk biochar on chemical properties of tropical wetland soil, rice growth and yield. Aust J Crop Sci 12: 817-826. DOI: 10.21475/ajcs.18.12.05.PNE1043

Khachatourians GG, Qazi SS, Reid WR. 2007. Biochemistry and molecular biology of entomopathogenic fungi. In: Brakhage AA, Zipfer PF (eds.). The Mycota VI: Human and animal relationships. Springer-Verlag, Berlin.

Liu SF, Wang GJ, Nong XQ, Liu B, Wang M, Li SL, Cao GC, Zhang ZH. 2017. Entomopathogen Metarhizium anisopliae promotes the early development of Peanut Root. Plant Protect Sci 53: 101-107. DOI: 10.17221/49/2016-PPS

Luo Z, Ren H, Mousa JJ, Rangel DEN, Zhang Y, Bruner SD, Keyhani NO. 2017. The PacC transcription factor regulates secondary metabolite production and stress response, but has only minor effects on virulence in the insect pathogenic fungus Beauveria bassiana. Environ Microbiol 19: 788-802. DOI: 10.1111/1462-2920.13648

Mancillas-Paredes JM, Hernández-Sánchez H, Jaramillo-Flores ME, García-Gutiérrez C. 2019. Proteases and chitinases induced in 
Beauveria bassiana during infection by Zabrotes subfasciatus. Southwestern Entomol 44: 125-137. DOI: 10.3958/059.044.0114

Maqsood S, Sabri, MA, Ali A, Abbas M, Aziz A. 2017. Comparative toxicity of some insecticides against army worm, Spodoptera litura L. (Lepidoptera: Noctuidae) under laboratory conditions. J Entomol Zool Stud 5: 770-773.

Maryanto M, Sukiyono K, Priyono B. 2018. Technical efficiency analysis and determinants in potato farming (Solanum tuberosum L.) in Pagar Alam City, South Sumatra Province. Agraris 4: 1-8. DOI: 10.18196/agr.4154 [Indonesian]

Mascarin GM, Jackson MA, Behle RW, Kobori NN, Júnior ÍD. 2016. Improved shelf life of dried Beauveria bassiana blastospores using convective drying and active packaging processes. Appl Microbiol Biotechnol 100: 8359-8370. DOI: 10.1007/s00253-016-7597-2

Mascarin GM, Jackson MA, Kobori NN, Behle RW, Delalibera Júnior Í. 2015. Liquid culture fermentation for rapid production of desiccationtolerant blastospores of Beauveria bassiana and Isaria fumosorosea strains. J Invertebr Pathol 127: 11-20. DOI: 10.1016/j.jip.2014.12.001

Munir J, Herman W. 2019. Various physical and soil chemical properties phenomena support food security in West Sumatera. Ziraa'ah 44: 146-153. DOI: 10.31602/zmip.v44i2.1736. [Indonesia]

Nagal G. Verma K, Rathore L. 2016. Management of Spodoptera litura (Fabricius) through some novel insecticides and biopesticides on bell pepper under polyhouse environment. Adv Life Sci 5: 1081-1084.

Nasution K, Respatijarti. 2019. Yield trial on eight potential lines F7 generation of chili pepper (Capsicum Annuum L.) compact type in Low Land. J Produksi Tanaman 7: 464-473. [Indonesian]

Oreste M, Baser N, Bubici G, Tarasco E. 2015. Effect of Beauveria bassiana strains on the Ceratitis capitata - Psyttalia concolor system. Bull Insectol 68: 265-272.

Peña-Peña AJ, Santillán-Galicia MT, Hernández-López J, Guzmán-Franco AW. 2015. Metarhizium pingshaense applied as a seed treatment induces fungal infection in larvae of the white grub Anomala cincta. J Invertebr Pathol 130: 9-12. DOI: 10.1016/j.jip.2015.06.010

Pinnamaneni R., Kalidas P, Rao KRSS. 2010. Cloning and Expression of Bbchit1 gene of Beauveria bassiana. Open Entomol J 4: 30-35. DOI: 10.2174/1874407901004010030

Prabawati G, Herlinda S, Pujiastuti Y. 2019. The abundance of canopy arthropods in South Sumatra (Indonesia) freshwater swamp main and ratooned rice applied with bioinsecticides and synthetic insecticide. Biodiversitas 20: 2921-2930. DOI: 10.13057/biodiv/d201021

Qazi SS, Khachatourians GG. 2008. Addition of exogenous carbon and nitrogen sources to aphid exuviae modulates synthesis of proteases and chitinase by germinating conidia of Beauveria bassiana. Arch Microbiol 189 (6): 589-596.

Safitri A, Herlinda S, Setiawan, A. 2018. Entomopathogenic fungi of soils of freshwater swamps, tidal lowlands, peatlands, and highlands of South Sumatra, Indonesia. Biodiversitas 19: 2365-2373. DOI: 10.13057/biodiv/d190647

Sagrim M, Sumule AI, Iyai DA, Baransano M. 2017. Prime potency of agriculture commodities on highland of Arfak Mountains Regency, Papua Barat. J Ilmu Pertanian Indonesia 22: 141-146. [Indonesian]. DOI: $10.18343 /$ jipi.22.3.141

Situmorang S, Haryono D, Soelaiman A. 2019. Analysis of business performance and welfare of vegetable farmers in Pagar Alam City South Sumatera Province. Indon J Socio Econ 1: 84-92. [Indonesian]

Soesanto L, Mugiastuti E, Manan A. 2019. Raw secondary metabolites application of two Trichoderma harzianum isolates towards vascular streak dieback on cocoa seedlings. Pelita Perkebunan 35: 22-32. DOI: 10.22302/iccri.jur.pelitaperkebunan.v35i1.346

Sumikarsih E, Herlinda S. Pujiastuti Y. 2019. Conidial density and viability of Beauveria bassiana isolate from java and Sumatra and their virulence against Nilaparvata lugens at different temperatures. Agrivita 1: 335-349. DOI: 10.17503/agrivita.v41i2.2105

Turnip A, Runtuboi DYP, Lantang D. 2018. Effectivity test of Beauveria bassiana fungus and application time of Spodoptera litura in mustard greens (Brassica juncea). J Biologi Papua 10: 26-31. DOI: 10.31957/jbp.131. [Indonesian]

Vijaya M, Rani PU. 2017. Defensive responses in Capsicum annuum (L) plants, induced due to the feeding by different larval instars of Spodoptera litura (F). Arthropod-Plant Interact 11: 193-202.

Zamhari A, Sitorus S, Pravitasari A. 2017. Analysis of the competitive commodities and its direction of development plan in Pagar Alam City, South Sumatera Province. Tata Loka 19: 218-229. DOI: 10.14710/tataloka.19.3.218-229. [Indonesian]

Zibaee A, Bandani AR, Talaei-Hassanlouei R, Malagoli D. 2011. Cellular Immune Reactions of the Sunn Pest, Eurygaster integriceps, to the Entomopathogenic Fungus, Beauveria bassiana and its secondary metabolites. J Insect Sci 11: 1-16. DOI: 10.1673/031.011.13801

Zibaee A, Bandani AR, Tork M. 2009. Effect of the entomopathogenic fungus, Beauveria bassiana, and its secondary metabolite on detoxifying enzyme activities and acetylcholinesterase (AChE) of the Sunn pest, Eurygaster integriceps (Heteroptera: Scutellaridae). Biocontrol Sci Technol 19: 485-498. DOI: 10.1080/09583150902847127. 